\section{Mycophenolate mofetil: a step forward in the induction treatment of ANCA-associated vasculitis? Comment on the article by Jones et al}

We have read with interest the results of the MYCYC trial showing that mycophenolate mofetil (MMF) is not inferior to intravenous cyclophosphamide (CYC) in achieving a primary remission in the treatment of ANCA-associated vasculitides (AAV). ${ }^{1}$ We would like to address several comments.

First, in a previous report of the MYCYC trial in 2013, the authors could not establish a non-inferiority of MMF compared with CYC because the lower bound of the $90 \% \mathrm{CI}$ of the absolute risk difference (RD) crossed the prespecified non-inferiority margin of $-12 \%$ (MMF: $n=46 / 70(66 \%)$ vs CYC: $n=48 / 70$ (69\%), $\mathrm{RD}=-3 \%, 90 \% \mathrm{CI}-16 \%$ to $10 \%$, $\mathrm{p}=0.06) .^{2}$ In the current publication, the reported primary remission rates at 6 months are slightly different compared with the princeps abstract (MMF: $n=47 / 70$ (67\%) vs CYC: $\mathrm{n}=43 / 70(61 \%))$, leading this time to a non-inferiority of MMF compared with CYC regarding the primary endpoint $(\mathrm{RD}=5.7 \%, 90 \% \mathrm{CI}-7.5 \%$ to $19 \%$, $\mathrm{p}$ value $=$ not reported $)$. As the number of included patients are equal in each group between the two publications, suggesting that the study populations are the same, we would be interested to learn what can explain these discrepancies in results.

Beyond these statistical issues, these results could impact future AAV guidelines by expanding the recommendation of MMF use to cases more severe than the non-life or nonorgan threatening mentioned in EUVAS/EULAR guidelines (which state that MMF is an alternative to oral methotrexate in such patients). ${ }^{3}$ Indeed, patients included in the MYCYC trial display a level of severity similar to those from the RAVE study ${ }^{4}$ in terms of renal involvement. In MYCYC, median eGFR was $51 \mathrm{~mL} / \mathrm{min} / 1.73 \mathrm{~m}^{2}$ in both arms whereas in the RAVE study, median eGFR was 54 and $69 \mathrm{~mL} / \mathrm{min} / 1.73 \mathrm{~m}^{2}$ in the rituximab (RTX) and the CYC arms, respectively. The renal exclusion criteria in MYCYC were an eGFR $<15 \mathrm{~mL} /$ $\min / 1.73 \mathrm{~m}^{2}$ or a rapidly declining renal function, whereas the RAVE trial stated a creatininemia above $4 \mathrm{mg} / \mathrm{dL}$. The comparison between activity scores of the two trials is hampered by the use of BVAS V.2003 in MYCYC versus BVAS-WG in RAVE (see table 1 for the comparison between the two studies).

The statement that MMF and RTX are both non-inferior to CYC should be interpreted with caution, in particular, in antiPR3-AAV patients who are at high risk of relapse and henceas highlighted by the authors-would not represent good candidates for an induction treatment with MMF, as it is associated with a higher risk of relapses than CYC. ${ }^{2}$ These results confirm those of the IMPROVE trial, showing that-contrary to lupus nephritis maintenance treatment and prevention of solid-organ graft rejection-MMF was associated to more relapses than azathioprine. ${ }^{5}$ Conversely, in a post hoc analysis of RAVE, patients with anti-PR3-AAV responded better to RTX than to induction with CYC followed by maintenance with azathioprine, whereas no association between treatment and complete remission were observed in the anti-MPO-AAV patient subset. ${ }^{6}$

Finally, in severe patients (at least with anti-PR3 ANCA), one could still prefer RTX or CYC to MMF because RTX, the maintenance treatment that has shown the best efficacy in the MAINRITSAN 1 trial, $^{7}$ has only been used in maintenance after an induction with either $\mathrm{CYC}^{7}$ or RTX (RITAZAREM study - unpublished results).

\section{Frédéric Alain Vandergheynst $\odot{ }^{1}$ Christophe Lelubre ${ }^{2}$ \\ ${ }^{1}$ Internal Medicine, Hôpital Erasme, Bruxelles, Belgium \\ ${ }^{2}$ Internal Medicine, CHU de Charleroi - Hôpital Civil Marie Curie, Charleroi, Belgium}

Correspondence to Professor Frédéric Alain Vandergheynst, Internal Medicine, Hopital Erasme, 1070 Bruxelles, Belgium; Frederic.Vandergheynst@erasme.ulb.ac. be

Handling editor Josef Smolen

Table 1 Comparison between MYCYC ${ }^{1}$ and RAVE ${ }^{4}$

\begin{tabular}{|c|c|c|}
\hline & MYCYC & RAVE \\
\hline Design & Unblinded RCT & Blinded RCT \\
\hline Non-inferiority margin & $12 \%$ & $20 \%$ \\
\hline Excluded patients & $\begin{array}{l}\text { Imminent life-threatening } \\
\text { eGFR }<15 \mathrm{~mL} / \mathrm{min} / 1.73 \mathrm{~m}^{2} \text { and/or rapidly declining } \\
\text { renal function }\end{array}$ & $\begin{array}{l}\text { Creatinine }>4 \mathrm{mg} / \mathrm{dL} \\
\text { Alveolar haemorrhage requiring mechanical ventilation }\end{array}$ \\
\hline Comparator & Intravenous CYC (EUVAS scheme) & Oral CYC \\
\hline Median eGFR (mL/min/1.73 $\left.\mathrm{m}^{2}\right)$ & 51 for both arms & 54 (RTX arm) and 69 (CYC arm), $p=0.04$ \\
\hline Median BVAS 2003 & 19 (MMF arm) and 18 (CYC arm) & Not applicable \\
\hline Median BVAS-WG & Not applicable & 8.5 (RTX) and 8.2 (CYC) (NS) \\
\hline Renal involvement & $81 \%$ for both arms & $66 \%$ for both arms \\
\hline Serious adverse events (SAE) & $\begin{array}{l}73 \text { for } 70 \text { patients (MMF arm) versus } 64 \text { for } 70 \text { patients } \\
\text { (CYC arm) (NS) }\end{array}$ & $\begin{array}{l}\text { Only SELECTED SAE: } \\
31 \text { for } 99 \text { patients (RTX arm) versus } 33 \text { for } 98 \text { patients (CYC } \\
\text { arm) (NS) }\end{array}$ \\
\hline $\begin{array}{l}\text { Primary endpoint definition: } \\
\text { Complete remission (CR) rate at month } 6 \text { with adherence } \\
\text { to prednisone tapering scheme } \\
\text { Definition of } C R \\
\text { Objective of tapering }\end{array}$ & $\begin{array}{l}\text { BVAS } 2003=0 \\
\text { PDN=5 mg/day at month } 6\end{array}$ & $\begin{array}{l}\text { BVAS-WG }=0 \\
\text { PDN }=0 \mathrm{mg} / \text { day at month } 6\end{array}$ \\
\hline Primary endpoint achievement & $\begin{array}{l}67 \% \text { for the MMF arm } \\
61 \% \text { for the CYC arm } \\
\text { (p value for non-inferiority not reported) }\end{array}$ & $\begin{array}{l}64 \% \text { for the RTX arm } \\
53 \% \text { for the CYC arm } \\
\text { ( }<<0.001 \text { for non-inferiority) }\end{array}$ \\
\hline
\end{tabular}

BVAS, Birmingham Vasculitis Activity Score; BVAS-WG, BVAS-Wegener; CYC, cyclophosphamide; eGFR, estimated glomerular filtration rate; EUVAS, European Vasculitis Study Group; MMF, mycophenolate mofetil; NS, Not significant; PDN, Prednisone; RCT, randomised controlled trial; RTX, rituximab; SAE, serious adverse events. 
Contributors I hereby certify that both the authors have brought a significant contribution in the content of this manuscript.

Competing interests None declared.

Patient consent for publication Not required.

Provenance and peer review Not commissioned; internally peer reviewed.

(C) Author(s) (or their employer(s)) 2020. No commercial re-use. See rights and permissions. Published by BMJ.

\section{(A) Check for updates}

To cite Vandergheynst FA, Lelubre C. Ann Rheum Dis 2020;79:e100.

Received 30 April 2019

Accepted 3 May 2019

Published Online First 22 May 2019

\section{CLinked}

http://dx.doi.org/10.1136/annrheumdis-2019-215658

Ann Rheum Dis 2020;79:e100. doi:10.1136/annrheumdis-2019-215647
ORCID iD

Frédéric Alain Vandergheynst http://orcid.org/0000-0002-1388-9262

\section{REFERENCES}

1 Jones RB, Hiemstra TF, Ballarin J, et al. Mycophenolate mofetil versus cyclophosphamide for remission induction in ANCA-associated vasculitis: a randomised, non-inferiority trial. Ann Rheum Dis 2019;78:399-405.

2 Jones R, Harper L, Ballarin J, et al. A randomized trial of mycophenolate mofetil versus cyclophosphamide for remission induction of ANCA-associated vasculitis: "MYCYC". On behalf of the European vasculitis study group. Presse Med 2013:42:678-9.

3 Yates M, Watts RA, Bajema IM, et al. EULAR/ERA-EDTA recommendations for the management of ANCA-associated vasculitis. Ann Rheum Dis 2016;75:1583-94.

4 Stone JH, Merkel PA, Spiera R, et al. RAVE-ITN Research Group. rituximab versus cyclophosphamide for ANCA-associated vasculitis. N Engl J Med 2010;363:221-32.

5 Hiemstra TF, Walsh M, Mahr A, et al. Mycophenolate mofetil vs azathioprine for remission maintenance in antineutrophil cytoplasmic antibody-associated vasculitis: a randomized controlled trial. JAMA 2010:304:2381-8.

6 Unizony S, Villarreal M, Miloslavsky EM, et al. Clinical outcomes of treatment of antineutrophil cytoplasmic antibody (ANCA)-associated vasculitis based on ANCA type. Ann Rheum Dis 2016;75:1166-9.

7 Guillevin L, Pagnoux C, Karras A, et al. Rituximab versus azathioprine for maintenance in ANCA-associated vasculitis. N Eng/ J Med 2014;371:1771-80. 